\title{
The amino acids profile of the brain and eyes of African giant pouch rat (Cricetomys gambianus)
}

\author{
Mojisola Adenike Oyarekua ${ }^{1}$ and Emmanuel Ilesanmi Adeyeye ${ }^{2}$,* \\ ${ }^{1}$ Department of Biological and Chemical Sciences, \\ University of Science and Technology, P.M.B. 306, Ifaki Ekiti, Nigeria. \\ ${ }^{2}$ Department of Chemistry, University of Ado-Ekiti, P.M.B. 5363, Ado-Ekiti, Nigeria \\ *Corresponding author: E-mail: eiadeyeye@yahoo.com, Tel: +2348035782925
}

\begin{abstract}
The amino acid composition of the brain and eyes of the matured female African giant pouch rat (Cricetomys gambianus) was determined on dry weight basis. The total essential amino acids ranged from 36.2-36.9 g/100 g crude protein or from 48.1-49.9 \% of the total amino acids. The amino acid score showed that lysine ranged from $0.81-0.85$ (on whole hen's egg comparison), 0.92-0.95 (on provisional essential amino acid scoring pattern) and 0.87-0.90 (on suggested requirement of the essential amino acid of a preschool child). The predicted protein efficiency ratio was $1.58-2.08$, the essential amino acid index range was 1.10-1.10 and the calculated isoelectric point range was 4.28-4.25. The correlation coefficient $\left(r_{x y}\right)$ was highly positive and significant at $r=0.05$ for the total amino acids, amino acid scores (on all the comparisons made) and the isoelectric point in the two samples. Results have good comparison with whole hen's egg protein and other standard proteins.
\end{abstract} \section{INTRODUTION}

Keywords: Cricetomys gambianus, brain, eyes, amino acid profiles.

The Gambian pouch rat (Cricetomys gambianus), also known as the African giant pouch rat is a nocturnal rat of the giant pouched rat genus Cricetomys. It is the largest muroid in the world. It is native to Africa (http://en.wikipedia.org/wiki/GambianPouch-Rat).

The Gambian pouch rat can grow to be as big as a raccoon and can weigh up to $4 \mathrm{~kg}$. It has very poor eyesight and so depends on its senses of smell and hearing. Its name comes from the large, hamster-like pouches in its cheeks. It is not a true rat, but is part of a uniquely African branch of muroid rodents. In its native Africa, this rat lives in colonies of up to twenty, usually in forests and thickets, but also commonly in termite mounds. It is omnivorous, feeding on vegetables, insects, crabs, snails, and other items, but apparently preferring palm fruits and kernels (Novak and Paradiso, 1991).

Unlike domestic rats, it has cheek pouches like a hamster. These cheek pouches allow it to gather up several kilograms of nuts per night for storage underground. It has been known to stuff its pouches so full of date palm nuts so as to be hardly able to squeeze through the entrance of its burrows. The burrow consists of a long passage with side alleys and several chambers, one for sleeping and the others for storage (Van der Straeten et al., 2004). The African giant pouch rat belongs to the Order Rodentia, Superfamily Muroidea, Family Nesomyidae, Subfamily Cricetomyinae, Genus Cricetomys, Species C. gambianus., Binomial name: Cricetomys gambianus Waterhouse, 1840 (http://en.wikipedia.org/wiki/Gambian-Pouch-Rat). In Africa, it is routinely eaten as bushmeat. It (and other mammals) is referred to by the pidgin name of "beef".

A study carried out in Nigeria showed that the giant rat produces about the same amount of meat as the domestic rabbit (Den Hartog and de Vos, 1973). The meat's nutritional value compares favourably with that of domestic livestock and African villagers know how to prepare it by smoking or by salting [National Research Council (NRC), 1991]. The head of the giant rat is a delicacy for the African child; however, no literature is available on the amino acids profile of the brain and eyes eaten by the African child. This work was therefore set out to evaluate the amino acids profile of the brain and eyes of the African giant pouch rat, the information derived here would also 
likely improve the information on food composition tables.

\section{MATERIALS AND METHODS}

Preparation of samples: C. gambianus matured female samples were caught in the wild by a local hunter commissioned for the purpose at Iworoko Ekiti, Nigeria; identified, immersed in hot water (10 min), hair removed and the animals dissected. The head was partially dried; brain and eyes were then separately removed and dried to constant weight; milled into flour and kept in freezer in McCartney bottles pending analysis. Three animal samples were involved where the brain and eyes were put together respectively as composite samples.

Crude protein determination and fat extraction: The micro-Kjeldahl method as described by Pearson (1976) was followed to determine the fat-free crude protein. The fat was extracted with a chloroform/methanol $(2: 1 \mathrm{v} / \mathrm{v})$ mixture using Soxhlet extraction apparatus (AOAC, 2005).

Amino acid analysis: Between $30 \mathrm{mg}$ and $35 \mathrm{mg}$ defatted samples were weighed into glass ampoule, $7 \mathrm{ml}$ of $6 \mathrm{M} \mathrm{HCl}$ added and hydrolyzed in an oven preset at $105 \pm 5^{\circ} \mathrm{C}$ for $22 \mathrm{~h}$. Oxygen was expelled in the ampoule by passing nitrogen gas into it. Amino acid analysis was done by ion-exchange chromatography (Spackman et al., 1958) using a Technicon Sequential Multisample Amino Acid Analyzer (Technicon Instruments Corporation, New York, USA). The period of analysis was $76 \mathrm{~min}$, with a gas flow rate of $0.50 \mathrm{ml} / \mathrm{min}$ at $60^{\circ} \mathrm{C}$, and the reproducibility was $\pm 3 \%$. Tryptophan was not determined.

Estimation of isoelectric point (pl): The theoretical estimation of isoelectric point (pl) was determined using the equation of Olaofe and Akintayo (2000) and information provided by Finar (1975):

$I P m=\sum_{i=1}^{n} I P, X$

Where IPm $=$ the isoelectric point of the $\mathrm{i}^{\text {th }}$ amino acid in the mixture;

$X_{i}=$ the mass or mole fraction of the $i^{\text {th }}$ amino acid in the mixture.

Estimation of predicted protein efficiency ratio ( $P$ - PER): The predicted protein efficiency ratio ( $P$ PER) was estimated by using the equation of the form (Alsmeyer et al., 1974):

$\mathrm{P}-\mathrm{PER}=-0.468+0.454($ Leu $)-0.105$ (Tyr)
Estimation of dietary protein quality: The amino acid scores were calculated using three different procedures:

(i) Scores based on amino acid values compared with whole hen's egg amino acid profile (Paul et al.,1976);

(ii) Scores based on essential amino acid scoring pattern (FAO/WHO, 1973);

(iii) Scores based on essential amino acid suggested pattern of requirements for preschool child (FAO/WHO/UNU, 1985).

Estimation of essential amino acid index (EAAI): The essential amino acid index (EAAI) was determined using the method of Steinke et al. (1980).

Leucine/isoleucine ratio: The leucine/isoleucine ratios, their differences and their percentage differences were also calculated.

Statistical analysis: The statistical analysis carried out included the determination of the grand mean, standard deviation (SD) and the coefficients of variation percent (CV \%). Other calculations made were the simple linear correlation coefficient $\left(r_{x y}\right)$, coefficient of determination $\left(r_{x y}{ }^{2}\right)$, coefficient of alienation (or index of lack of relationship) $\left(C_{A}\right)$ and index of forecasting efficiency (IFE) and subjected to table standards to test for significance difference, the level of probability was set at $r_{0.05}$ at $n-2$ degrees of freedom (Oloyo, 2001).

\section{RESULTS AND DISCUSSION}

Table 1 presents the amino acid composition of the samples. Glu and Asp were the most concentrated amino acid (AA) in both the brain and the eyes with respective values of 12.1-13.0 g/100 g crude proteins (Glu) and 10.0-6.95 g/100 g crude proteins, cp (Asp). A look at Table 1 will show that AA of the brain was slightly less concentrated (on pair wise comparisons) than the corresponding AA in the eyes in seven or $41.2 \%$ parameters; of the nine essential AA determined, six of them or $66.7 \%$ were more concentrated in the eyes than the brain on pair wise comparisons. The most concentrated essential AA (EAA) in the samples were Arg $(5.95 \mathrm{~g} / 100 \mathrm{~g} \mathrm{cp})$ in the brain and Leu (6.34 g/100 $\mathrm{g} \mathrm{cp}$ ) in the eyes. The coefficient of variation percent (CV \%) ranged between $0.0-25.4$ in the AA, with Phe having the least CV \% and Asp the highest CV \%. From literature, the EAA with Cys and Tyr values had been given for the brain of cattle, pig and sheep (Fornias, 
1996); for cattle brain, values in g/100 gcp were: Leu (7.5), Ile (3.9), Lys (6.0), Met (2.1), Cys (1.8), Phe (5.0), Tyr (3.6), Thr (4.7), Val (4.9), His (2.5) and total (42.8); for pig brain: Leu (8.7), lle (4.6), Lys (7.8), Met (2.0), Cys (-), Phe (5.1), Tyr (4.2), Thr (4.7), Val (5.7), His (2.7) and total (46.8); for sheep brain: Leu (7.8), Ile (4.0), Lys (6.4), Met (2.0), Cys (1.1), Phe (4.8), Tyr (3.7), Thr (4.5), Val (4.8), His (2.6) and total (42.8). With these literature values, our EAA results in the brain can be described as follows: Leu (5.35) was close to all the literature samples; lle (3.24), Lys (5.05), Tyr (3.59), Thr (3.01) and Val (4.05) were very close to all the literature samples whereas Cys (1.02) was close to cattle and sheep brains results but better than the pig; Met (2.60), Phe (4.28) and His (2.62) were better than the literature brain values respectively except in Phe; the total of $34.8 \mathrm{~g} / 100 \mathrm{~g}$ was close to the literature values (Try was not determined in our samples). The total value for the eyes was $35.3 \mathrm{~g} / 100 \mathrm{~g}$ crude protein.

Table 1: Amino acid composition (g/100 g crude protein) of the brain and eyes of African giant pouch rat (dry weight)

\begin{tabular}{|l|l|l|l|l|l|}
\hline $\begin{array}{l}\text { Amino } \\
\text { acid }\end{array}$ & Brain & Eyes & Mean & SD & CV \% \\
\hline Lys & 5.05 & 5.24 & 5.15 & 0.13 & 2.61 \\
\hline His & 2.62 & 2.26 & 2.44 & 0.25 & 10.4 \\
\hline Arg & 5.95 & 5.52 & 5.74 & 0.30 & 5.30 \\
\hline Asp & 10.0 & 6.95 & 8.48 & 2.16 & 25.4 \\
\hline Thr & 3.01 & 3.36 & 3.19 & 0.25 & 7.76 \\
\hline Ser & 3.00 & 3.29 & 3.15 & 0.21 & 6.51 \\
\hline Glu & 12.1 & 13.0 & 12.6 & 0.64 & 5.05 \\
\hline Pro & 2.21 & 2.59 & 2.40 & 0.27 & 11.2 \\
\hline Gly & 4.10 & 3.74 & 3.92 & 0.25 & 6.49 \\
\hline Ala & 2.96 & 3.50 & 3.23 & 0.38 & 11.8 \\
\hline Met & 2.60 & 2.86 & 2.73 & 0.18 & 6.73 \\
\hline Cys & 1.02 & 0.75 & 0.89 & 0.19 & 21.5 \\
\hline Val & 4.05 & 3.15 & 3.60 & 0.64 & 17.7 \\
\hline Ile & 3.24 & 3.90 & 3.57 & 0.47 & 13.1 \\
\hline Leu & 5.35 & 6.34 & 5.85 & 0.70 & 12.0 \\
\hline Phe & 4.28 & 4.28 & 4.28 & 0.0 & - \\
\hline Tyr & 3.59 & 3.17 & 3.38 & 0.30 & 8.79 \\
\hline Try & - & - & - & - & - \\
\hline $\begin{array}{l}\text { Protein (fat } \\
\text { free) }\end{array}$ & 55.8 & 66.3 & 61.1 & 7.42 & 12.2 \\
\hline \multicolumn{7}{|l|}{$\begin{array}{l}\text { not determined; mean value is grand mean from the } \\
\text { mean values of the amino acid values. }\end{array}$} \\
\hline
\end{tabular}

The FAO/WHO/UNU (1985) standards for pre-school children (2 - 5 years) were ( $\mathrm{g} / 100 \mathrm{~g}$ protein): Leu (6.6), Phe + Tyr (6.3), Thr (3.4), Try (1.1), Val (3.5), lle (2.8), Lys (5.8), Met + Cys (2.5), His (1.9) and total (33.9 with His) and 32.0 (no His). Based on this information, the brain would provide enough or even more than enough of Phe + Tyr, Ile, Met + Cys, His and total EAA while the eyes would provide enough or even more of Leu, Phe + Tyr, Thr, lle, Met + Cys, His and total EAA. Tryptophan was not determined. Histidine is a semi-essential amino acid particularly useful for children growth. It is the precursor of histamine present in small quantities in cells. When allergens enter the tissues it is liberated in larger quantities and is responsible for nettle rash (Bingham, 1977). The value of lle was $3.24-3.90 \mathrm{~g} / 100 \mathrm{~g} \mathrm{cp}$ in the samples. It is an EAA for both old and young. Maple Syrup Urine Disease is an Inborn Error of metabolism in which brain damage and early death can be avoided by a diet low in Ile and two other EAA, Leu and Val. Both Ile, Leu and Val were high in the current report. Methionine is an EAA with value range of $2.60-2.86 \mathrm{~g} / 100 \mathrm{~g} \mathrm{cp}$ in this report or 3.62$3.61 \mathrm{~g} / 100 \mathrm{~g} \mathrm{cp}$ with Cys. Methionine is needed for the synthesis of choline. Choline forms lecithin and other phospholipids in the body. When the diet is low in protein, for instance in alcoholism and kwashiorkor, insufficient choline may be formed; this may cause accumulation of fat in the liver (Bingham, 1977). Phenylalanine formed a value range of 4.28-4.28 $\mathrm{g} / 100 \mathrm{~g} \mathrm{cp}$ of the samples. It is the precursor of some hormones and the pigment melanin in hair, eyes and tanned skin. Phenylketonuria is the commonest inborn error of metabolism successfully treated by diet. The absence of an enzyme in the liver blocks the normal metabolism of phenylalanine and the brain is irreversibly damaged unless a diet low in phenylalanine is given in the first few weeks of life. Tyrosine value range was 3.59-3.17 g/100 g cp. Tyrosine is the precursor of some hormones (like the thyroid hormones) and the brown pigment melanin formed in hair, eyes and tanned skin. It reduces the requirement of Phe. Permanent deficiency of the enzyme-hypertyrosinaemia, a rare inborn error of metabolism - can cause liver and kidney failure unless treated with a synthetic diet low in Phe and Tyr (Bingham, 1977). Valine an EAA is restricted in the treatment of Maple Syrup Urine Disease.

Table 2 presents parameters on the quality of the protein of the samples. The EAA ranged between $36.2-36.9 \mathrm{~g} / 100 \mathrm{~g} \mathrm{cp}$ with a variation of $1.35 \%$. These values were more than half the average of $56.6 \mathrm{~g} / 100 \mathrm{~g} \mathrm{cp}$ of the egg reference protein (Paul et al., 1976). The total sulphur AA (TSAA) of the samples were $3.62 \mathrm{~g} / 100 \mathrm{~g} \mathrm{cp}$ (brain) and $3.61 \mathrm{~g} / 100$ $\mathrm{g} \mathrm{cp}$ (eyes). The values of 3.62-3.61 g/100 g cp were close to the value of $5.8 \mathrm{~g} / 100 \mathrm{~g} \mathrm{cp}$ recommended for infants (FAO/WHO/UNU, 1985). The aromatic AA 
(ArAA) range suggested for infant protein (6.8-11.8 $\mathrm{g} / 100 \mathrm{~g} \mathrm{cp})$ (FAO/WHO/UNU, 1985) was very favourably comparable with the present report of 7.87-7.45 $\mathrm{g} / 100 \mathrm{~g} \mathrm{cp}$ showing that the samples protein could be used to supplement sorghum flour (Adeyeye, 2008a). The percentage ratio of EAA to the total AA (TAA) in the samples ranged between 48.1-49.9\%. These values were well above the $39 \%$ considered adequate for ideal protein food for infants, $26 \%$ for children and $11 \%$ for adults (FAO/WHO/UNU, 1985). The percentage of EAA/TAA for the samples could be favourably compared with other animal protein sources: $46.2 \%$ in Zonocerus variegatus (Adeyeye, 2005a), $43.7 \%$ in Macrotermes bellicosus (Adeyeye, 2005b) and 54.8 $\%$ in Gymnarchus niloticus (Trunk fish) (Adeyeye and Adamu, 2005) whereas it is $50 \%$ for egg (FAO/WHO, 1990). The TEAA in these results were close to the value of $44.4 \mathrm{~g} / 100 \mathrm{~g} \mathrm{cp}$ in soybean (Kuri et al., 1991), melon and gourd oilseeds with respective values of $53.4 \mathrm{~g} / 100 \mathrm{~g} \mathrm{cp}$ and $53.6 \mathrm{~g} / 100 \mathrm{~g} \mathrm{cp}$ (Olaofe et al., 1994). The percentage of total neutral AA (TNAA) ranged from 52.4-55.3, indicating that these formed the bulk of the $A A$; total acidic AA (TAAA) ranged from 29.4-27.1 which were far lower than \% TNAA, while the percentage range in total basic AA (TBAA) was 18.1-17.6 which made them the third largest group among the samples. The predicted protein efficiency ratio (P-PER) was 1.58 (brain) and 2.08 (eyes). These results were highly comparable to the following literature values: 2.27 (skin) and 1.93 (muscle) of turkey hen (Adeyeye and Ayejuyo, 2007); it is 2.22 (Clarias anguillaris), 1.92 (Oreochromis niloticus) and 1.89 (Cynoglossus senegalensis) (Adeyeye, 2009) but lower than in the values from various parts of fresh water female crab: 3.4 (whole body), 3.1 (flesh), 2.6 (exoskeleton) (Adeyeye 2008b); fresh water male crab: 2.9 (whole body), 2.8 (flesh), 2.4 (exoskeleton) (Adeyeye and Kenni, 2008); 4.06 (corn ogi) and reference casein with PER of 2.50 (Oyarekua and Eleyinmi, 2004); 2.56 (cattle brain), 3.04 (pig brain) and 2.68 (sheep brain) (Fornias, 1996). Other literature values were 1.21 (cowpea), 1.82 (pigeon pea) (Salunkhe and Kadam, 1989); 1.62 (millet ogi) and 0.27 (sorghum ogi) (Oyarekua and Eleyinmi, 2004); greater than 0.00 (raw sorghum), 0.23 (steeped sorghum) and 0.29 (germinated sorghum) (Adeyeye, 2008a). The Leu/lle ratio was low in both samples (1.65-1.63) with CV \% of 0.86; hence no concentration antagonism might be experienced in the giant pouch rat brain and eyes when used as protein source in food. The essential AA index (EAAl) ranged from 1.10 (brain) - 1.10 (eyes). EAAl is useful as a rapid tool to evaluate food formulations for protein quality, although it does not account for differences in protein quality due to various processing methods or certain chemical reactions (Nielsen, 2002). The EAAI of defatted soybean is 1.26 (Nielsen, 2002); this is close to the present results. In the results of the isoelectric points (pl), there was a shift from 4.28 (brain) down to 4.25 (eyes). This type of shift was also observed in turkey meat: from 4.41 in skin to 5.01 in the muscle (Adeyeye and Ayejuyo, 2007). The calculation of pl from amino acids would assist in the production of the protein isolate of an organic product.

Table 2: EAA, non-EAA, acidic, neutral, sulphur and aromatic acid contents (g/100 g crude protein) of the brain and eyes of African giant pouch rat (dry weight)

\begin{tabular}{|c|c|c|c|c|c|}
\hline Amino acid & Brain & Eyes & Mean & SD & $\begin{array}{l}\mathrm{CV} \\
\%\end{array}$ \\
\hline $\begin{array}{l}\text { Total amino } \\
\text { acids (TAA) }\end{array}$ & 75.2 & 73.9 & 74.6 & 0.92 & 1.23 \\
\hline $\begin{array}{l}\text { Total non- } \\
\text { essential amino } \\
\text { acid (TNEAA) }\end{array}$ & 39.0 & 37.0 & 38.0 & 1.41 & 3.72 \\
\hline Total EAA & & & & & \\
\hline With His & 36.2 & 36.9 & 36.6 & 0.49 & 1.35 \\
\hline No His & 33.6 & 34.6 & 34.1 & 0.71 & 2.07 \\
\hline$\%$ TNEAA & 51.9 & 50.1 & 51.0 & 1.27 & 2.50 \\
\hline \% Total EAA & & & & & \\
\hline With His & 48.1 & 49.9 & 49.0 & 1.27 & 2.60 \\
\hline No His & 44.7 & 46.8 & 45.8 & 1.48 & 3.24 \\
\hline $\begin{array}{l}\text { Total neutral } \\
\text { amino acid } \\
\text { (TNAA) }\end{array}$ & 39.4 & 40.9 & 40.2 & 1.06 & 2.64 \\
\hline$\%$ TNAA & 52.4 & 55.3 & 53.9 & 2.05 & 3.80 \\
\hline $\begin{array}{l}\text { Total acidic } \\
\text { amino acid } \\
\text { (TAAA) }\end{array}$ & 22.1 & 20.0 & 21.1 & 1.48 & 7.04 \\
\hline$\%$ TNAA & 29.4 & 27.1 & 28.3 & 1.63 & 5.75 \\
\hline $\begin{array}{l}\text { Total basic } \\
\text { amino acid } \\
\text { (TBAA) }\end{array}$ & 13.6 & 13.0 & 13.3 & 0.42 & 3.19 \\
\hline$\%$ TBAA & 18.1 & 17.6 & 17.6 & 0.71 & 4.02 \\
\hline $\begin{array}{l}\text { Total sulphur } \\
\text { amino acid } \\
\text { (TSAA) }\end{array}$ & 3.62 & 3.61 & 3.62 & 0.01 & 0.20 \\
\hline$\%$ TSAA & 4.82 & 4.88 & 4.85 & 0.04 & 0.87 \\
\hline$\%$ Cys in TSAA & 28.2 & 20.8 & 24.5 & 5.23 & 21.4 \\
\hline $\begin{array}{l}\text { Total aromatic } \\
\text { amino acid } \\
\text { (TArAA) }\end{array}$ & 7.87 & 7.45 & 7.66 & 0.30 & 3.88 \\
\hline$\%$ TArAA & 10.5 & 10.1 & 10.3 & 0.28 & 2.75 \\
\hline P-PER & 1.58 & 2.08 & 1.83 & 0.35 & 19.3 \\
\hline Leu/lle ratio & 1.65 & 1.63 & 1.64 & 0.01 & 0.86 \\
\hline $\begin{array}{l}\text { Leu-Ile } \\
\text { (difference) }\end{array}$ & 2.11 & 2.44 & 2.28 & 0.23 & 10.2 \\
\hline $\begin{array}{l}\text { \% Leu-Ile } \\
\text { (difference) }\end{array}$ & 39.4 & 38.5 & 39.0 & 0.64 & 1.63 \\
\hline EAAI & 1.10 & 1.10 & 1.10 & 0.0 & - \\
\hline $\begin{array}{l}\text { Isoelectric point } \\
\text { (pl) }\end{array}$ & 4.28 & 4.25 & 4.27 & 0.02 & 0.50 \\
\hline
\end{tabular}


Most animal proteins are low in Cys, for examples: $36.3 \%$ in $M$. bellicosus (Adeyeye, 2005b), $25.6 \%$ in Z. variegatus (Adeyeye, 2005a); $35.5 \%$ in Archachatina marginata; $38.8 \%$ in Archatina archatina and $21.0 \%$ in Limicolaria sp.; respectively (Adeyeye and Afolabi, 2004); $27.3 \%-32.8 \%$ in female fresh water crab body parts (Adeyeye, 2008b); $23.8 \%-30.1 \%$ in three different Nigeria fishes (Adeyeye, 2009); $13.3 \%-15.9 \%$ in male fresh water crab body parts (Adeyeye and Kenni, 2008); $26.0 \%$ $26.5 \%$ in turkey hen meat (Adeyeye and Ayejuyo, 2007) in their (Cys/TSAA) \% values. The present results corroborated these literature observations with values of 28.4 down to $20.8 \%$. In contrast, many vegetable proteins contain substantially more Cys than Met, examples (Cys/TSAA) \%: $62.9 \%$ in coconut endosperm (Adeyeye, 2004); and in Anacardium occidentale it is $50.5 \%$ (Adeyeye et al., 2007); and 58.9-72.0 in sorghum (raw, steeped, germinated) (Adeyeye, 2008a). Thus, for animal protein diets or mixed diets containing animal protein, Cys is unlikely to contribute up to $50 \%$ of the TSAA (FAO/WHO, 1991). The percentage of Cys in TSAA had been set at $50 \%$ in rat, chick and pig diets (FAO/WHO, 1991). Cys can spare with Met in improving protein quality and has positive effects on mineral absorption, particularly zinc (Mendoza, 2002; Sandstrom et al., 1989).

Table 3 shows the AA scores (AAS) of the samples based on whole hen's egg profile (Paul et al., 1976). The scores had values greater than 1.0 in His, Glu and Gly in the brain; they were Glu and Gly in the eyes. Glycine had the highest score (1.37) in brain and 1.25 in the eyes; the least score was Ser (0.38) in the brain and that position was shared by Cys, Ser and $\mathrm{Val}(0.42)$ in the eyes. The African giant pouch rat head organs (brain and eyes) generally showed good comparisons with the AA profile of the whole hen's egg. The CV \% between AA levels of brain and eyes ranged between 0.0-25.1. Table 4 shows the essential AA scores (EAAS) based on the provisional amino acid scoring pattern (FAO/WHO, 1973). The EAAS greater than 1.0 in the brain were Phe $+\mathrm{Tyr}$ and Met + Cys and they were also Phe + Tyr and Met + Cys in the eyes. The limiting AA (LAA) in the brain was Thr (0.75) whereas it was also $\mathrm{Val}(0.63)$ in the eyes. Although these would have been described as the LAA, however, the EAA most often acting in a limiting capacity are methionine (and cysteine), lysine, threonine and tryptophan (FAO/WHO/UNU, 1985). Since Try was not determined, Thr would be limiting in brain (0.75) and the eyes (0.84). To make corrections for the LAA in the samples if they serve as sole sources of protein food therefore, it would be $100 / 75.0 \times$ protein of brain and 100/84.0 x protein of eyes; or $1.33 \times$ protein of brain and $1.19 \times$ protein of eyes (Bingham, 1977). The highest EAAS in the brain was Phe + Tyr (1.31) and also Phe + Tyr (1.24) in the eyes. The Table 5 shows the EAAS based on suggested requirement of the EAA of a preschool child (FAO/WHO/UNU, 1985). It is interesting to note that Thr, Leu and Lys had EAAS less than 1.0 in brain whereas Lys, Thr, Val and Leu had EAAS less than 1.0 in the eyes. Unlike in Table 4, Met + Cys had the highest score (1.45) in the brain and in the eyes (1.44). The LAA in brain was Lys (0.87) and also Lys in the eyes (0.90) (based on the above reasoning) with respective corrections of $100 / 87.0$ (1.15) $x$ protein of brain and 100/90.0 (1.11 x protein of eyes.

The following values would show the position of the quality of the African giant pouch rat brain and eyes protein: the EAA requirements across board are (values with His) (g/100g protein): infant (46.0), preschool (2 - 5 years) (33.9), school child (10 - 12 years) (24.1) and adult (12.7) and without His: infant (43.4), pre-school (32.0), school child (22.2) and adult (11.1) (FAO/WHO/UNU, 1985); from the present results based on these standards, we have: $36.2 \mathrm{~g}$ protein (with His) and 33.6 (no His) in brain; $36.9 \mathrm{~g}$ protein (with His) and 34.6 (no His) in eyes. While the present results would satisfy a high percentage of infant needs, they will satisfy the requirements of preschool children and above.

Table 6 gave a brief summary of the AA profile in the two samples. Column under factor $B$ means showed that the values there were very close with a range of 36.6-38.0. However, Table 7 depicts the summary of the statistical analysis of results in Tables 1, 2 (pl only) 3, 4 and 5. The simple linear correlation coefficient $\left(r_{x y}\right)$ values showed high positive and significant results from Tables 1, 2 (pl only), 3, 4 and 5 but $r_{x y}$ values being highest in 1 and 2 at $r_{=0.05}$ and $n-2$ degrees of freedom. The regression coefficient $\left(R_{x y}\right)$ showed that for every unit increase in the brain AA parameter, the increase was 0.32 (Table 1), 1.20 (Table 2, pl only), 0.15 (Table 3), 0.27 (Table 4) and 0.38 (Table 5) in the eye AA parameter. 
Table 3: Amino acid scores of the brain and eyes of the African giant pouch rat based on whole hen's egg amino acid profile

\begin{tabular}{|l|l|l|l|l|l|}
\hline $\begin{array}{l}\text { Amino } \\
\text { acid }\end{array}$ & Brain & Eyes & Mean & SD & $\begin{array}{l}\text { CV } \\
\%\end{array}$ \\
\hline Lys & 0.81 & 0.85 & 0.83 & 0.03 & 3.41 \\
\hline His & 1.09 & 0.94 & 1.02 & 0.11 & 10.4 \\
\hline Arg & 0.98 & 0.90 & 0.94 & 0.06 & 6.02 \\
\hline Asp & 0.93 & 0.65 & 0.79 & 0.20 & 25.1 \\
\hline Thr & 0.59 & 0.66 & 0.63 & 0.05 & 7.92 \\
\hline Ser & 0.38 & 0.42 & 0.40 & 0.03 & 7.07 \\
\hline Glu & 1.01 & 1.09 & 1.05 & 0.06 & 5.39 \\
\hline Pro & 0.58 & 0.68 & 0.63 & 0.07 & 11.2 \\
\hline Gly & 1.37 & 1.25 & 1.31 & 0.08 & 6.48 \\
\hline Ala & 0.55 & 0.65 & 0.60 & 0.07 & 11.8 \\
\hline Cys & 0.57 & 0.42 & 0.50 & 0.11 & 21.4 \\
\hline Val & 0.54 & 0.42 & 0.48 & 0.08 & 17.7 \\
\hline Met & 0.81 & 0.89 & 0.85 & 0.06 & 6.66 \\
\hline Ile & 0.58 & 0.70 & 0.64 & 0.08 & 13.3 \\
\hline Leu & 0.64 & 0.76 & 0.70 & 0.08 & 12.1 \\
\hline Tyr & 0.90 & 0.79 & 0.85 & 0.08 & 9.20 \\
\hline Phe & 0.84 & 0.84 & 0.84 & 0.0 & - \\
\hline & & & & &
\end{tabular}

Table 4: Amino acid scores of the brain and eyes of the African giant pouch rat based on the provisional amino acid scoring pattern

\begin{tabular}{|l|l|l|l|l|l|}
\hline $\begin{array}{l}\text { Amino } \\
\text { acid }\end{array}$ & Brain & Eyes & Mean & SD & CV \% \\
\hline Lys & 0.92 & 0.95 & 0.94 & 0.02 & 2.27 \\
\hline Thr & 0.75 & 0.84 & 0.80 & 0.06 & 8.00 \\
\hline Met+Cys & 1.03 & 1.03 & 1.03 & 0.0 & - \\
\hline Val & 0.81 & 0.63 & 0.72 & 0.13 & 17.7 \\
\hline Ile & 0.81 & 0.98 & 0.90 & 0.12 & 13.4 \\
\hline Leu & 0.76 & 0.91 & 0.84 & 0.11 & 12.7 \\
\hline Phe+Tyr & 1.31 & 1.24 & 1.28 & 0.05 & 3.88 \\
\hline Try & - & - & - & - & - \\
\hline Total & 0.92 & 0.94 & 0.93 & 0.01 & 1.52 \\
\hline
\end{tabular}

The coefficient of alienation $\left(\mathrm{C}_{\mathrm{A}}\right)$ was low in Table 1 (0.332 or $33.2 \%)$, Table 2 (0.265 or $26.5 \%)$ and Table $3(0.480$ or $48.0 \%)$ but high in Table $4(0.608$ or $60.8 \%)$ and $5(0.671$ or $67.1 \%)$. The index of forecasting efficiency (IFE) was high in Table 1 (0.668 or $66.8 \%)$, Table 2 (0.735 or $73.5 \%)$ and Table $3(0.520$ or $52.0 \%)$ while others were low at between 32.9-39.2 \% (Tables 5 and 4). Low IFE versus high $C_{A}$ makes prediction of relationship difficult. The $\mathrm{C}_{\mathrm{A}}$ produces an index of lack of relationship while the IFE gives the reduction in errors of prediction or relationship. The $\mathrm{C}_{\mathrm{A}}$ and IFE values showed that a good relationship existed between the brain and eyes AA in Cricetomys gambianus particularly with the results in Tables 1,2 and 3. The pattern of $r_{x y}$ results from Tables 1 and 2 were similar to those obtained for the amino acid profiles of the shell and flesh of Penaeus notabilis (Adeyeye et al., 2008).

Table 5: Amino acid scores of the brain and eyes of the African giant pouch rat based on the suggested requirement of the essential amino acid of a preschool child

\begin{tabular}{|l|l|l|l|l|l|}
\hline Amino acid & Brain & Eyes & Mean & SD & CV \% \\
\hline Lys & 0.87 & 0.90 & 0.89 & 0.02 & 2.40 \\
\hline His & 1.38 & 1.19 & 1.29 & 0.13 & 10.4 \\
\hline Thr & 1.89 & 0.99 & 0.94 & 0.07 & 7.52 \\
\hline Val & 1.16 & 0.90 & 1.03 & 0.18 & 17.8 \\
\hline Met+Cys & 1.45 & 1.44 & 1.45 & 0.01 & 0.49 \\
\hline Ile & 1.16 & 1.39 & 1.28 & 0.16 & 12.7 \\
\hline Leu & 0.81 & 0.96 & 0.89 & 0.11 & 11.9 \\
\hline Phe+Tyr & 1.25 & 1.18 & 1.22 & 0.05 & 4.06 \\
\hline Try & - & - & - & - & - \\
\hline Total & 1.06 & 1.08 & 1.07 & 0.01 & 1.32 \\
\hline
\end{tabular}

Table 6: Summary of the amino acid profiles into factors $A$ and $B$

\begin{tabular}{|l|c|c|c|}
\hline \multicolumn{3}{|c|}{$\begin{array}{c}\text { Samples } \\
\text { (factor A) }\end{array}$} \\
\hline \multicolumn{3}{|c|}{ Brain Eyes } & Factor B means \\
\hline $\begin{array}{l}\text { Amino acid } \\
\text { composition } \\
\text { (Factor B) }\end{array}$ & 36.2 & 36.9 & 36.6 \\
\hline $\begin{array}{l}\text { Total essential } \\
\text { amino acid } \\
\begin{array}{l}\text { Total non-essential } \\
\text { amino acid }\end{array}\end{array}$ & 39.0 & 37.0 & 38.0 \\
\hline Factor A means & 37.6 & 37.0 & 37.3 \\
\hline
\end{tabular}

Table 7: Summary of the statistical analysis of the data in Tables 1, 2, 3, 4 and 5

\begin{tabular}{|l|l|l|l|l|l|c|}
\hline $\begin{array}{l}\text { From } \\
\text { Table }\end{array}$ & $\mathrm{r}_{\mathrm{xy}}$ & $\mathrm{r}_{\mathrm{xy}}{ }^{2}$ & $\mathrm{R}_{\mathrm{xy}}$ & $\mathrm{C}_{\mathrm{A}}$ & $\mathrm{IFE}$ & Remark \\
\hline 1 & 0.9440 & 0.89 & 0.32 & 0.332 & $\begin{array}{c}66.8 \\
\%\end{array}$ & $*$ \\
\hline $\begin{array}{l}2 \\
(\mathrm{pl} \\
\text { only) }\end{array}$ & 0.9630 & 0.93 & 1.20 & 0.265 & $\begin{array}{c}73.5 \\
\%\end{array}$ & $*$ \\
\hline 3 & 0.8778 & 0.77 & 0.15 & 0.480 & $\begin{array}{c}52.0 \\
\%\end{array}$ & $*$ \\
\hline 4 & 0.7965 & 0.63 & 0.27 & 0.608 & 39.2 & $*$ \\
\hline 5 & 0.7396 & 0.55 & 0.38 & 0.671 & 32.9 & $*$ \\
\hline
\end{tabular}

* Result significant at $r=0.05$ at $n-2$ degrees of freedom. 
CONCLUSION: This study has presented the amino acid data of the head organs (brain and eyes) of African giant pouch rat Cricetomys gambianus female. It was found that the samples were good sources of high quality protein of almost adequate or more than adequate of essential amino acids, low Leu/lle ratio and high protein efficiency ratio values thereby providing a probable premium quality meat. The analysis of the eyes would also improve the information in the food composition Tables.

\section{REFERENCES}

Adeyeye, E.I., (2004). The chemical composition of liquid and solid endosperm of ripe coconut, Orient. J. Chem., 20(3): 471-476.

Adeyeye, E.I., (2005a). Amino acid composition of variegated grasshopper, Zonocerus variegatus. Trop. Sci., 45(4): 141-143.

Adeyeye, E.I., (2005b). The composition of the winged termites, Macrotermes bellicosus. J. Chem. Soc. Nig., 30(2): 145-149.

Adeyeye, E.I., (2008a). The intercorrelation of the amino acid quality between raw, steeped and germinated guinea corn (Sorghum bicolor) grains, Bull Chem. Soc. Ethiop., 22(1): 11-17.

Adeyeye, E.I., (2008b). Amino acid composition of the whole body, flesh and exoskeleton of female common West African fresh water crab Sudananautus africanus africanus, Int. J. Food Sci. Nutr., 59(7-8): 699-705.

Adeyeye, E.I., (2009). Amino acid composition of three species of Nigerian fish: Clarias anguillaris, Oreochromis niloticus and Cynoglossus senegalensis. Food Chemistry, 113: 43-46.

Adeyeye, E.I. and Adamu, A.S., (2005). Chemical composition of food properties of Gymnarchus niloticus (Trunk fish). Biosci. Biotechnol Res. Asia, 3(2): 265272.

Adeyeye, E.I. and Afolabi, E.O., (2004). Amino acid composition of three different types of land snails consumed in Nigeria, Food Chem, 85: 535-539.

Adeyeye, E.I., and Ayejuyo, O.O., (2007). Proximate, amino acids and mineral composition of turkey-hen muscle and skin, Orient. J. Chem, 23(3): 879-886.

Adeyeye, E.I., and Kenni, A.M., (2008). The relationship in the amino acid of the whole body, flesh and exoskeleton of male common West African fresh water crab Sudananautus africanus africanus, Pak. J. Nutr., 7(6): 748-752.

Adeyeye, E.I., Adubiaro, H.O. and Awodola, O.J., (2008). Chemical composition and functional properties of shell and flesh of Penaeus notabilis, Pak. J. Nutr., 7(6): 741-747.

Adeyeye, E.I., Asaolu, S.S. and Aluko, A.O., (2007). Amino acid composition of two masticatory nuts (Cola acuminata and Garcinia kola) and a snack nut (Anacardium occidentale), Int. J. Food Sci. Nutr., 58 (4): 241-249.

Alsmeyer, R.H., Cunningham, A.E. and Happich, M.L., (1974). Equations to predict PER from amino acid analysis. Food Technology, 28: $34-38$.

AOAC., (2005). Official Methods of Analysis. $18^{\text {th }}$ edn. Association of Official Analytical Chemists, Washington DC.

Bingham, S., (1977). Dictionary of Nutrition, Barrie and Jenkins, London.

Den Hartog, A.P. and de Vos, A., (1973). The use of rodents as food in tropical Africa. Nutrition Reports International (FAO), 11(2): 1-14.

Finar, I.L., (1975). Organic Chemistry, Vol. 2. $5^{\text {th }}$ edn. ELBS and Longman Group, London.

FAO/WHO., (1973). Energy and Protein Requirements. Technical report series, No. 522, Geneva, Switzerland.

FAO/WHO., (1990). Protein Quality Evaluation. Report of Joint FAO/WHO consultation, Bethesda MD, 4-8 December, 1989. FAO/WHO, Rome.

FAO/WHO., (1991). Protein Quality Evaluation. Report of joint FAO/WHO expert Consultation, FAO Food Nutrition paper No. 51. FAO/WHO, Rome.

FAO/WHO/UNU. (1985). Energy and Protein Requirements. Technical report series, No. 724, Geneva, Switzerland.

Fornias, O.V., (1996). Edible by-products of slaughter animals. FAO animal production and health paper, 123. FAO, Rome.

Kuri, Y.E., Sundar, R.K., Kahuwi, C., Jones, G.P. and Rivett, D.E., (1991). Chemical composition of Monerdica charantis L. fruits. J. Agric. Food Chem. 39: 1702-1703.

Mendoza, C., (2002). Effect of genetically modified low phytic acid plants on mineral absorption. Int. J. Food Sci. Technol, 37: 759-767.

NRC (National Research Council), (1991). Microlivestock: little - known small animals with a promising economic future. National Academy Press, Washington DC.

Novak, R.M. and Paradiso, J.L., (1991). Walkers Mammals of the World, Vol. II. Johns Hopkins University Press, Baltimore.

Nielsen, S.S., (2002). Introduction to the Chemical Analysis of Foods, CBS Publishers and Distributors, New Delhi. 
Agric. Biol. J. N. Am., 2011, 2(2): 368-375

Olaofe, O. and Akintayo, E.T., (2000). Prediction of isoelectric points of legume oilseed proteins from their amino acid composition, The J. Technosci., 4: 49 - 53.

Olaofe ,O., Adeyemi, F.O. and Adediran, G.O., (1994). Amino acid and mineral compositions and functional properties of some oilseeds. J. Agric. Food Chem. 1994; 42(4): 879-881.

Oloyo, R.A., (2001). Fundamentals of Research Methodology for Social and Applied Sciences, ROA Educational Press, Ilaro, Nigeria.

Oyarekua, M.A. and Eleyinmi, A.F., (2004). Comparative evaluation of the nutritional quality of corn, sorghum and millet ogi prepared by modified traditional technique. Food Agric. Environ., 2: 94-99.

Paul, A.A., Southgate, D.A.T. and Russel, J., (1976). First Supplement to McCance and Widdowsons's the Composition of Foods. Her Majesty's Stationery Office, London.

Pearson, D., (1976). Chemical Analysis of Foods. $7^{\text {th }}$ edn. Churchill Livingstone, London.
Salunkhe, D.K. and Kadam, S.S., (1989). Handbook of World Food Legumes Nutritional Chemistry, Processing Technology and Utilization, Boca Raton, CRC Press, Florida, USA.

Sandstrom, B., Almgren, A., Kivisto, B. and Cederblad, A., (1989). Effect of protein and protein source on zinc absorption in humans, J. Nutr. 119: 48-53. Spackman, D.H., Stein, W.H. and Moore, S., (1958). Chromatography of amino acids on sulphonated polystyrene resins. An improved system, Anal. Chem., 30: $1190-1205$.

Steinke, F.H., Prescher, E.E. and Hopkins, D.T., (1980) Nutritional evaluation (PER) of isolated soybean protein and combinations of food proteins, J. Food Sci. 45: 323-327.

Van der Straeten et al., (2004). Cricetomys gambianus (http://www.iucnredlist.org/search/details.php/5522/all) Retrieved on 11 May 2006.

http://en.wikipedia.org/wiki/Gambian Pouch Rat modified 06:14, 28 August 2007. 